\title{
All non-indigenous species were introduced recently? The case study of Cassiopea (Cnidaria: Scyphozoa) in Brazilian waters
}

\author{
ANDRÉ C. MORANDINI ${ }^{1}$, SERGIO N. STAMPAR ${ }^{2}$, MAXIMILIANO M. MARONNA $^{1}$ \\ AND FÁBIO L. DA SILVEIRA ${ }^{1}$ \\ ${ }^{1}$ Departamento de Zoologia, Instituto de Biociências, Universidade de São Paulo, Rua do Matão, travessa 14, n. 101, São Paulo, SP \\ 05508-090, Brazil, ${ }^{2}$ Departamento de Ciências Biológicas, Faculdade de Ciências e Letras, Universidade Estadual Paulista 'Júlio de \\ Mesquita Filho', Av. Dom Antônio, n. 2100, Assis, SP 19806-900, Brazil
}

\begin{abstract}
Upside-down jellyfish (genus Cassiopea) can be found in tropical coastal waters worldwide. Until now reports of the genus from Brazilian waters have been scant. We report here medusae and scyphistomae collected from Cabo Frio, Rio de Janeiro state. Although we could not unambiguously identify the material using morphological criteria, genetic sequence data (COI) indicate that the Brazilian jellyfishes are genetically similar to those from Bermuda, Hawaii and Florida, which are related to specimens from the Red Sea (Cassiopea andromeda). We hypothesize that the presence of C. andromeda in Brazil is due to an invasion event, as the scyphistomae were found growing over the known invasive ascidian Styela plicata. Estimation of divergence time between Brazil (Cabo Frio) and Florida/Bermuda populations is that it occurred at the beginning of ship movement to South America.
\end{abstract}

Keywords: Invasive species, marine, rhizostome, jellyfish, blooms

Submitted 25 May 2015; accepted 24 February 2016; first published online 5 April 2016

\section{INTRDDUCTION}

Invasive alien species are the second greatest threat to global biodiversity loss (Sala et al., 1999). In the case of the marine environment, these invasive species may be escapees following intentional introduction, but are more usually the unintended consequence of global shipping and maritime transport (Carlton, 1987; Williams et al., 1988; Carlton \& Geller, 1993; Sax et al., 2007; Rodríguez-Labajos et al., 2009; Briski et al., 2012; Guo et al., 2012). Although most alien taxa that are introduced into new environments following ballast-water containment or hull-fouling fail to establish viable populations in their new environment (Carlton, 1996), a sufficiently large number do to warrant international programmes of prevention and control.

Although jellyfishes (Cnidaria: Medusozoa) have a number of biological features that allow them to be potentially invasive (Graham \& Bayha, 2007; Bayha \& Graham, 2014), there are relatively few species (five out of $\sim_{201}$; Bayha \& Graham, 2014) with proven reports of invasion worldwide, although with many records distributed in different ocean basins (Bayha \& Graham, 2014). Part of the reason for this must reflect an incomplete understanding of the biology, taxonomy and distribution of most jellyfishes (Dawson, 2005a), many of which have a number of cryptic species (Dawson, 2003; Holland et al., 2004), which was estimated as 7\% (Appeltans et al., 2012). In Brazilian waters (along $9230 \mathrm{~km}$ of coast)

Corresponding author:

A.C. Morandini

Email: acmorand@ib.usp.br only one (Phyllorhiza punctata von Lendenfeld, 1884; Moreira, 1961; Haddad \& Nogueira, 2006) of the 22 recorded species of scyphozoans (Morandini et al., 2005; Lopes et al., 2009) can be considered as exotic to date.

The genus Cassiopea is widely distributed across the globe in shallow tropical waters (Kramp, 1961). Although a total of 10 species are considered valid (Kramp, 1961; Hummelinck, 1968; Thiel, 1975), a number of genetically distinct lineages have been identified (Holland et al., 2004). Species of the genus can be abundant in disturbed/eutrophicated environments (Arai, 2001). Members of this genus have been considered invasive in the Mediterranean (Galil et al., 1990; Çevik et al., 2006; Schembri et al., 2010). Holland et al. (2004) also mapped the distribution of some populations and attributed the 'unusual' pattern observed to maritime transport.

The first report of the genus Cassiopea Péron \& Lesueur, 1810 in Brazil was published in 2002 (Migotto et al., 2002), although a number of sightings and grey-literature accounts pre-date that, but unfortunately without any voucher specimens.

Here we report specimens of Cassiopea from along the Brazilian coast using both morphological and molecular data and we compare our results with published information in order to try and determine their origin. The application of molecular (genetic) data to define and identify populations and species in marine research is now a well-recognized venture (Schander \& Willassen, 2005; Radulovici et al., 2010; De Broyer et al., 2011). Together with approaches such as morphology and ecology, this information let us analyse historical aspects such as time of possible invasion based on the divergence of Brazilian jellyfishes compared with the available data in the literature (Holland et al., 2004). 


\section{MATERIALS AND METHDDS}

\section{Field sampling}

Jellyfish specimens were sampled by hand at a small branch of the Itajuru Channel, a connection of the Araruama Lagoon to the open sea in Cabo Frio county, Rio de Janeiro state $\left(22^{\circ} 52^{\prime} 32^{\prime \prime} \mathrm{S} 42^{\circ} \mathrm{O1}^{\prime} \mathrm{O} 7^{\prime \prime} \mathrm{W}\right)$ (Figure 1) during the period November 2008 to October 2012 (weekly intervals from 2008-2009 and every 3 months from 2010-2012). Regular measurements of salinity, dissolved oxygen concentrations and temperature (recorded with an YSI 85 probe) indicate that salinity varied from $0-36$, water temperature from $26.6-28.7^{\circ} \mathrm{C}$, and dissolved oxygen from $7.01-15.56 \mu \mathrm{g} \mathrm{L}^{-1}$ in a period of $6 \mathrm{~h}$ (from high to low tide).

Medusae were preserved either in ethanol 95 or $4 \%$ formaldehyde solution in seawater. Two hundred freshly collected specimens were examined in the laboratory facilities to measure bell diameter, count number of rhopalia, lappets, mouth arms, define shape of the oral arm appendages and the organization of the canal system (with injection of dye). Morphological comparisons were conducted with descriptions in the literature as well as with specimens of Cassiopea frondosa (Pallas, 1774) and Cassiopea cf. xamachana Bigelow, 1892 that had been collected in February 2004 at Laguna Golf Club, Varadero (Cuba), and deposited at the Museu Nacional da Universidade Federal do Rio de Janeiro (MNRJ 5837 and 5838, respectively).

Scyphistomae morphologically resembling Cassiopea scyphistomae (Hofmann et al., 1978; Straehler-Pohl, 2009; Heins et al., 2015) were collected at the same place that

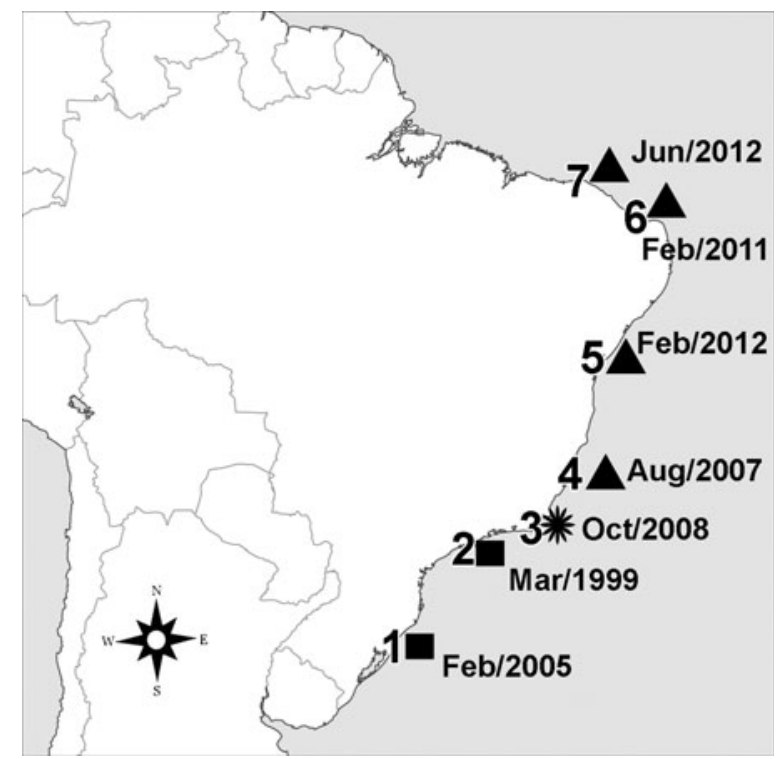

Fig. 1. Map of Brazil, showing records of Cassiopea Péron \& Lesueur, 1810 specimens. Squares refer only to polyp records $(1-2)$, triangles refer to medusa photographic records (4-7), star refers to sampling site at Cabo Frio (3), numbers after each symbol refer to date of first sighting in each area: (1) Imbé ( $29^{\circ} 58^{\prime} 26^{\prime \prime} \mathrm{S} 50^{\circ} 08^{\prime} 18^{\prime \prime} \mathrm{W}$; February 2005), Rio Grande do Sul state; (2) São Sebastião ( $23^{\circ} 49^{\prime} 41^{\prime \prime} \mathrm{S} 45^{\circ} 25^{\prime} 22^{\prime \prime} \mathrm{W}$; March 1999), São Paulo state; (3) Cabo Frio ( $22^{\circ} 52^{\prime} 32^{\prime \prime} \mathrm{S} 42^{\circ} \mathrm{O}^{\prime} \mathrm{O} 7^{\prime \prime} \mathrm{W}$; October 2008), Rio de Janeiro state; (4) Aracruz ( $19^{\circ} 50^{\prime} \mathrm{O}^{\prime \prime} \mathrm{S} 40^{\circ} 03^{\prime} 28^{\prime \prime} \mathrm{W}$; August 2007), Espírito Santo state; (5) Salvador ( $12^{\circ} 57^{\prime} 26^{\prime \prime} \mathrm{S} 38^{\circ} 31^{\prime} 50^{\prime \prime} \mathrm{W}$; February 2012), Bahia state; (6) Macau ( $5^{\circ} 0^{\prime} 53^{\prime \prime} \mathrm{S} 36^{\circ} 30^{\prime} 18^{\prime \prime} \mathrm{W}$; February 2011), Rio Grande do Norte state; (7) Itarema ( $02{ }^{\circ} 52^{\prime} 48^{\prime \prime} \mathrm{S} 39^{\circ} 54^{\prime} 15^{\prime \prime} \mathrm{W}$; June 2012), Ceará state. medusae were found. The scyphistomae were found growing on a variety of substrata, including plastic, wood and rubber shoes as well as on the exotic ascidian Styela plicata (Lesueur, 1823). Ten scyphistomae (Figure 2) were measured in the laboratory following the parameters proposed by Straehler-Pohl et al. (2011).

Voucher specimens of medusae and scyphistomae were deposited at the Museu de Zoologia da Universidade de São Paulo (MZUSP, 1944, 1945).

\section{Molecular protocols}

DNA was extracted from the oral arms removed from three specimens of medusae using an Agencourt DNAdvance ${ }^{\circledR}$ kit (\#A48708); DNA extraction from scyphistomae was not successful. Partial gene sequences were amplified using PCR, Universal PCR primers for the cytochrome oxidase I gene (COI) were used to amplify $\sim 500$ base pairs of this protein coding mitochondrial gene, using the original PCR program (forward $\mathrm{LCO}_{1490}$ and reverse $\mathrm{HCO}_{2} 198$ primers; Folmer et al., 1994). The PCR products were purified with the Agencourt AMPure ${ }^{\circledR}$ kit (\#A63881) and this amplified DNA sequences were prepared to sequencing using the Applied Biosystems BigDye ${ }^{\circledR}$ Terminator v3.1 kit (\#4337455), with the same primers and temperature conditions from the PCR's reactions. The sequencing procedure was carried out on a Hitachi ABI PRISM ${ }^{\circledR} 3100$ genetic analyser.

\section{DNA analysis}

Sequences were assembled and edited using Geneious ${ }^{\mathrm{TM}}$ 5.4.4 (Drummond et al., 2011), and new sequences were deposited in GenBank (KC464458-KC464459). COI sequences were compared to those of the other Cassiopea specimens available in GenBank (see table 1 in Holland et al., 2004): sequence alignment was made using the MUSCLE plugin in Geneious $^{\mathrm{TM}} \quad$ 5.4.4 (default parameters) (Edgar, 2004). Kimura's two-parameter model of base substitution and p-distance was used to calculate genetic distances in MEGA 6.05 software (Tamura et al., 2011). The Maximum Likelihood analysis was conducted via PHyML 3.0.1 beta with a more inclusive model, the general time reversible model with gamma values estimated directly from data (GTR + GAMMA) (Guindon et al., 2010). The Maximum Parsimony analysis was conducted via MEGA 5.05 (Tamura

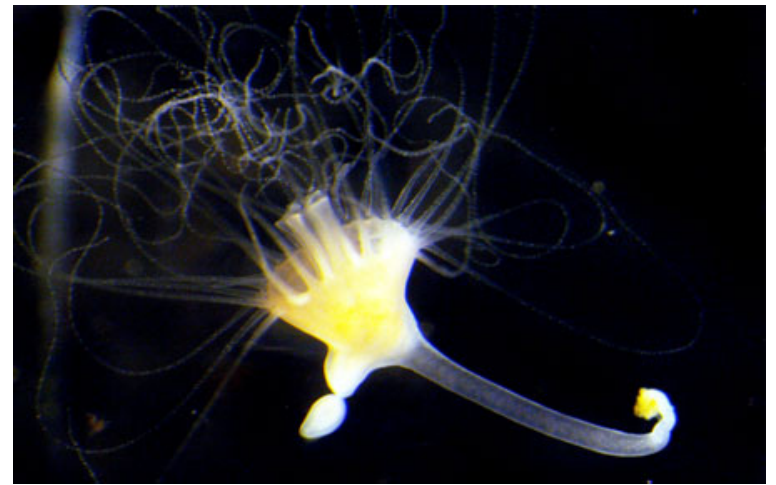

Fig. 2. Cassiopea andromeda (Forskål, 1775) scyphistoma just after collection, note long stalk and planuloid budding at the base of calyx; polyp $\sim_{5} \mathrm{~mm}$ long. 
et al., 2011): optimal tree was obtained by the search of optimal tree space using the Close-Neighbour-Interchange (CNI) algorithm (see more in Stampar et al., 2012). Support estimation was assessed with two non-parametric methods: bootstrap (500 pseudoreplicates) and SH-aLRT test (Anisimova et al., 2011) in PHyML 3.0.1 beta (Figure 3).

\section{RESULTS AND DISCUSSIDN}

The morphological and range meristic characters determined from the 200 specimens collected at Cabo Frio are shown in Table 1 in comparison with data from the other presently recognized species in the genus. It should be noted that all inspected specimens were males, suggesting that the population is perhaps maintained through asexual reproduction at the scyphistoma stage. The morphological and meristic data indicate that, with the possible exception of Cassiopea frondosa, it is not possible to distinguish between the different species (see Table 1) using the selected character set because of the high level of overlap between species (see Mayer, 1910; Kramp, 1961; Hummelinck, 1968; Thiel, 1975; Holland et al., 2004). The exception, Cassiopea frondosa, can be separated from the other recognized species by the number of rhopalia (12, although some variation is also found) and it is clear that the Brazilian material is not of this species.

Collected scyphistomae were also measured $(\mathrm{N}=10)$ : oral disc diameter $0.65-1.5 \mathrm{~mm}$; total length 2-3.5 mm; stalk length $1.15-2.5 \mathrm{~mm}$; calyx length $0.35-0.5 \mathrm{~mm}$; hypostome length $0.2-0.7 \mathrm{~mm}$; number of tentacles $27-36$. These measurements are in accordance with the available data for the genus (Ludwig, 1969; Straehler-Pohl, 2009). The scyphistomae were kept in laboratory conditions, and produced ephyrae (by monodisc strobilation) similar to the young medusae found in the field.

The COI data obtained from the three sequenced specimens were identical. The phylogenetic analysis (Figure 3)

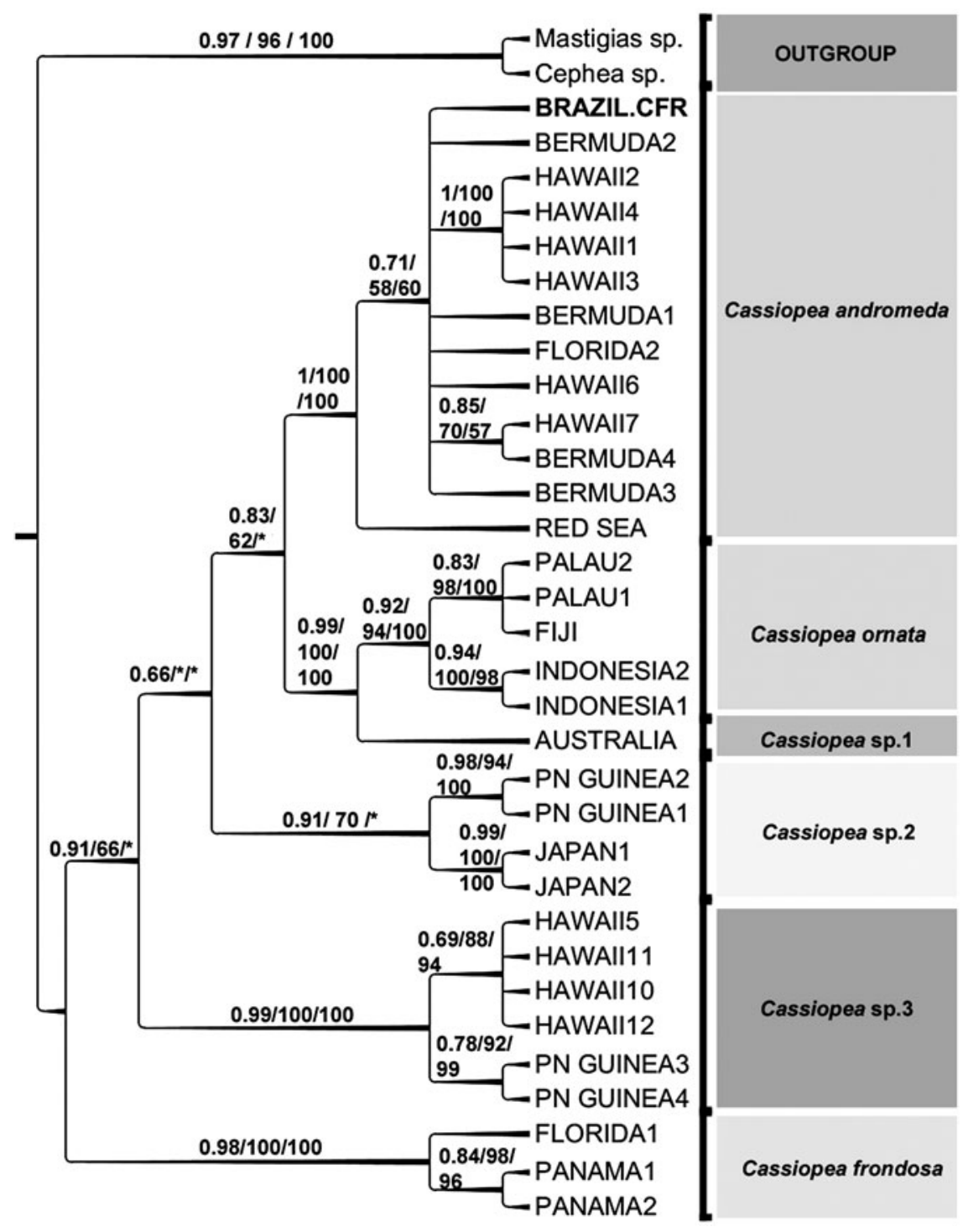

Fig. 3. Left panel - Cladogram representation for maximum likelihood tree (ML) of Cassiopea species with support values on branches (as in figure order: $\mathrm{SH}$-aLRT/maximum parsimony's tree bootstrap result/maximum likelihood bootstrap) ${ }^{*}=$ less than 50 ; in cases where figure permits, ML bootstrap values are below their respective branch. Right panel: phylogram representation only for same result (ML phylogram). 
Table 1. Comparison of available characters from the literature of the 10 valid/nominal species of the genus Cassiopea Péron \& Lesueur, 1810 (species list from Mayer, 1910; Kramp, 1961; Gershwin et al., 2010). $n=$ several appendages, not specified on the papers. For mouth arms we are considering number of branches, type of branching and general shape, according to the descriptions.

\begin{tabular}{|c|c|c|c|c|c|c|}
\hline Species & Size $\mathrm{cm}$ & Rhopalia & Lappets & Mouth arms & Appendages & Type locality \\
\hline C. andromeda (Forskål, 1775) & $10-12$ & $16 ?$ & variable & 4-6 branches & $\begin{array}{l}n \text { small, } 5 \text {-more } \\
\text { large/arm }\end{array}$ & Red Sea \\
\hline C. depressa Haeckel (1880) & $10-12$ & $16 ?$ & 144 & $6-8$ branches & $n$ small & $\begin{array}{l}\text { Madagascar, } \\
\text { Mozambique }\end{array}$ \\
\hline C. frondosa (Pallas, 1774) & $12-26$ & 12 & 60 & & $30-40$ small & $\begin{array}{l}\text { West Indies, } \\
\text { Caribbean }\end{array}$ \\
\hline $\begin{array}{l}\text { C. maremetens Gershwin, Zeidler \& } \\
\text { Davie (2011) }\end{array}$ & $2-20$ & 19 & 57 (3/rhopalia) & 4-6 branches & $\begin{array}{l}1 \text { - } 2 \text { central, } 1 \text { base } \\
\text { arm, } 1 \text { tip arm }\end{array}$ & $\begin{array}{l}\text { Lake Magellan, } \\
\text { Australia }\end{array}$ \\
\hline C. medusa Light (1914) & 26 & 17 & 119 ( $7 /$ rhopalia) & $\begin{array}{l}n \text { branches } \\
\qquad(3 \text { main distal })\end{array}$ & $n$ small/large & $\begin{array}{l}\text { Culion Bay, } \\
\text { Philippines }\end{array}$ \\
\hline C. mertensi Brandt (1835) & $10-12$ & $16 ?$ & 128 & $n$ branches & $n$ large & $\begin{array}{l}\text { Kosrae Island, } \\
\text { Micronesia }\end{array}$ \\
\hline C. ndrosia Agassiz \& Mayer (1899) & 5 & $18-22$ & 64 (4/rhopalia) & $?$ & $n$ leaf & Suva, Fiji \\
\hline C. ornata Haeckel (1880) & $10-12$ & $16 ?$ & 80 (5/rhopalia) & $?$ & $n$ small (only) & $\begin{array}{l}\text { Palau, Papua New } \\
\text { Guinea }\end{array}$ \\
\hline C. vanderhorsti Stiasny (1922) & 17 & $14-18$ & $\begin{array}{l}48-80(3-5 / \\
\text { rhopalia) }\end{array}$ & dichotomous & $n$ small/large & $\begin{array}{l}\text { Caracas Bay, } \\
\text { Curaçao }\end{array}$ \\
\hline C. xamachana Bigelow (1892) & 15 & $16 ?$ & 80 (5/rhopalia) & $\begin{array}{l}\text { Triangular } 10-15 \\
\text { alternate } \\
\text { branches }\end{array}$ & $n$ large ribbon & $\begin{array}{l}\text { Kingston Harbor, } \\
\text { Jamaica }\end{array}$ \\
\hline C. andromeda (from Cabo Frio) & $1-20$ & $16-22$ & $\begin{array}{c}48-80(3-5 / \\
\text { rhopalia })\end{array}$ & $\begin{array}{l}3-10 \text { (different } \\
\text { sizes) }\end{array}$ & $n$ small/large & $\begin{array}{l}\text { Cabo Frio, Rio de } \\
\text { Janeiro, Brazil }\end{array}$ \\
\hline
\end{tabular}

including the new Brazilian specimens, and terminals (=sequences) already presented in a previous study (Holland et al., 2004) clustered the Brazilian Cassiopea sequences group with the Cassiopea andromeda samples (from Florida, Bermuda and Hawaii) as defined by Holland et al. (2004). The molecular distance between the Brazilian material and Florida and Bermuda specimens is $0.54 \%$ based on Kimura 2-parameter model and 0.005 on p-distance (3 to 6 nucleotide variation). A comparison of the molecular divergence between the Cassiopea species considered by Holland et al. (2004) is shown in Table 2, and it reveals that intraspecific variation (from $0.6-10 \%$ ) is much smaller than interspecific variation (11-26\%). It is estimated that the C. andromeda specimens sampled here from Cabo Frio diverged from those in Florida and Bermuda $\sim 500$ years ago, which is relatively soon after the 'discovery' of Brazil in 1500 . In an alternative method (Dawson, 2005b) to estimate the divergence time between species the equation $T=\mathrm{d} / 2 \lambda$ (where $\mathrm{d}$ is the nucleotide distance between populations and the mutation rate $\lambda=$ $4.87 \times 10^{-6}$ ) was applied. Based on this equation the Cabo
Frio specimens diverged from Florida and Bermuda $\sim 554$ years ago.

Whilst early ships did not have the ballast capacity of modern vessels, and their ballast would invariably have been rocks or other heavy solid material, their hulls would have inevitably been subject to heavy fouling (see more in Carlton \& Hodder, 1995). An introduction into Brazil via the fouling route is perhaps more likely than by ballast water - although the scyphistomae of Cassiopea can produce a number of planuloids asexually on a daily basis (Hofmann et al., 1978), which could persist within ballast tanks - because scyphistomae were observed on artificial substrates as well as on another invasive species, Styela plicata (Barros et al., 2008). Given that genetic evidence (same haplotypes) indicates that Styela plicata populations off Florida and Brazil are similar (Barros et al., 2008), it is possible that populations of both species were introduced into Brazilian waters from Florida.

Cassiopea andromeda clearly has a number of ecological characteristics that predispose it to invasion success, chiefly

Table 2. Estimates of average evolutionary divergence over sequence pairs within and between 'species' as defined by Holland et al. (2004). Analyses were conducted using the Kimura 2-parameter model. The rate variation among sites was modelled with a gamma distribution (shape parameter $=1$ ). All positions containing gaps and missing data were eliminated (total positions in the final dataset: 554). Evolutionary analyses were conducted in MEGA5 (Drummond et al., 2011). $\mathrm{n} / \mathrm{c}=$ not possible to estimate evolutionary distances. Figure 3 lists the individuals used in the comparison as well as their location.

\begin{tabular}{|c|c|c|c|c|c|c|}
\hline & C. andromeda (\%) & C. frondosa (\%) & C. ornata (\%) & C. sp1 (\%) & C. sp2 (\%) & C. sp3 (\%) \\
\hline C. andromeda & 1.6 & 25 & 23 & 23 & 23 & 22 \\
\hline C. frondosa & & 1.3 & 26 & 25 & 24 & 22 \\
\hline C. ornata & & & 1.8 & 11 & 22 & 23 \\
\hline C. sp1 & & & & $\mathrm{n} / \mathrm{c}$ & 20 & 23 \\
\hline C. $\mathrm{sp}_{2}$ & & & & & 10 & 21 \\
\hline C. sp3 & & & & & & 0.6 \\
\hline
\end{tabular}




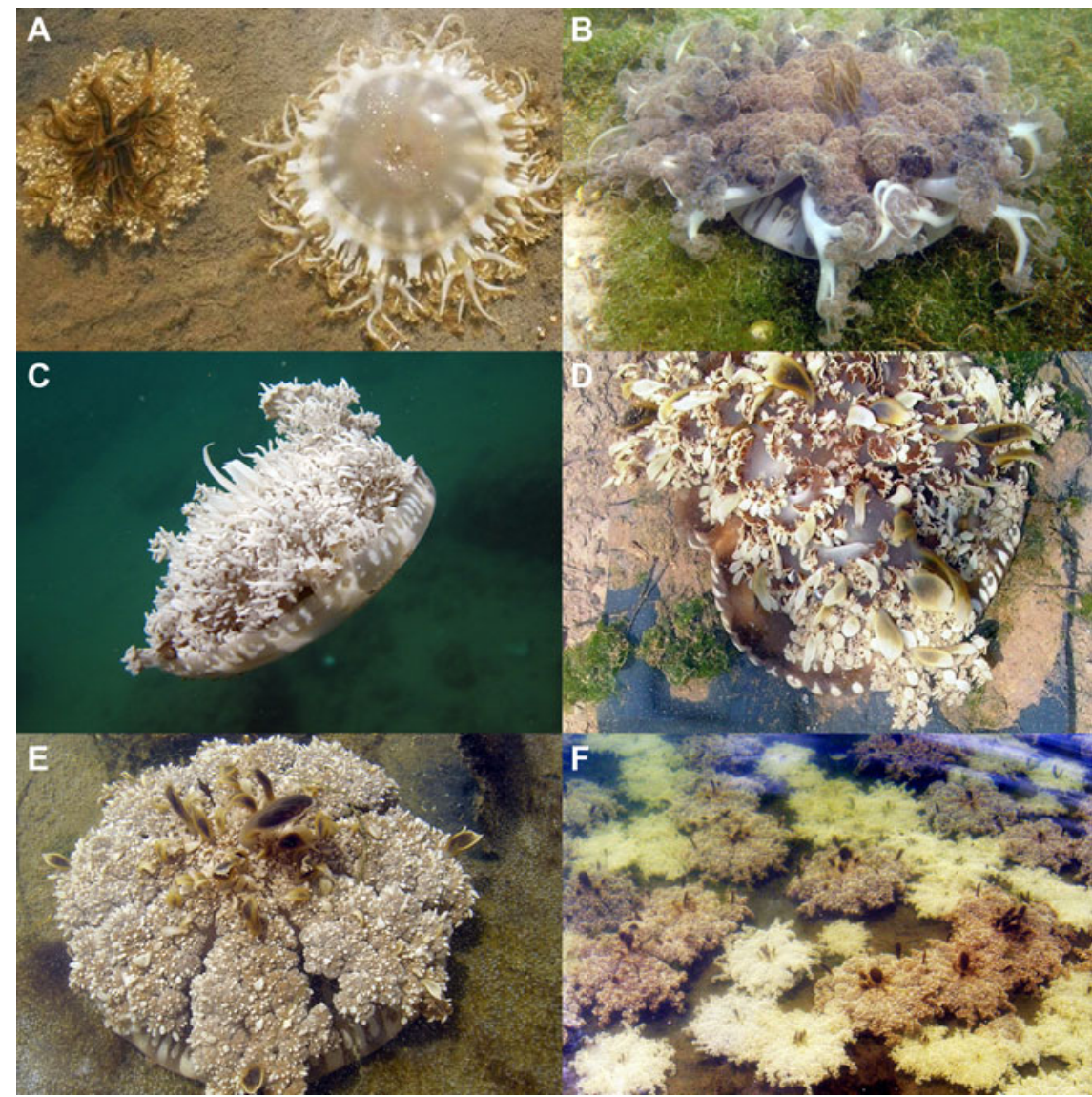

Fig. 4. Photographic records of Cassiopea Péron \& Lesueur, 1810 specimens from Brazilian coast (A-F). (A) Itarema, Ceará state (photo Carlos H.P. Marques \& Yara G. Oliveira); (B) Macau, Rio Grande do Norte state (photo Thelma L.P. Dias); (C) Salvador, Bahia state (photo Claudio L.S. Sampaio); (D) Aracruz, Espírito Santo state (photo Oberdan J. Pereira); (E-F) Cassiopea andromeda (Forskål, 1775) from Cabo Frio, Rio de Janeiro state (photos by André C. Morandini and Sergio N. Stampar).

the ability of its scyphistomae to produce planuloids at a high rate (personal observation). Off Brazil, it is clearly tolerant to quite wide variations in salinity and temperature (salinity o36 , water temperatures up to $\sim 29^{\circ} \mathrm{C}$ ), and this allows it to be an opportunistic species (Fofonoff et al., 2003; Devin \& Beisel, 2007; Zerebecki \& Sorte, 2011). It is known that Cassiopea species can be tolerant to salinity fluctuations (Goldfarb, 1914). Several other reports of Cassiopea medusae exist from the coast of Brazil based on photographic records (Figures 1 \& 4), as they do for scyphistomae (states of Rio Grande do Sul and São Paulo; Figure 1). Although we do not at this stage have genetic data to confirm their identity to species, it is clear that the genus Cassiopea is finding suitable habitats along the Brazilian coast and that in the future they may be much more common.

The detection of non-indigenous species in Brazilian waters is important (Rocha et al., 2013), because lists of such species shall serve as elements for conservation policies and priorities. Even as exhaustive biological surveys provide the best methods for detecting alien species, the appearance of unusual taxa in large numbers is often the first evidence of an invasion event. This is the case of the present species, with blooms of C. andromeda (Figure 5) in the Araruama Lagoon since 2008. But not all blooms of unusual species need be similarly interpreted owing to the lack of comprehensive species maps, the scarcity of long-term data on jellyfish blooms (Condon et al., 2012), and because jellyfish naturally exhibit episodic and seasonal interannual variability (Mills, 2001). We are aware that our genetic data only suggest the hypotheses of possible appearance of this species as following an invasive event in the Brazilian shoreline. Furthermore, whilst $C$. andromeda may have been resident in Brazilian waters for $\sim 500$ years, only now are populations (in some areas) blooming. The reasons for this are not yet understood, neither are the impacts on local biological communities, but to date there appear to be no obvious economic or social consequences of the bloom. Regardless, further work on the species in Brazil is now needed to define a broad and complete picture on present and past evolution of the species C. andromeda.

\section{ACKNDWLEDGEMENTS}

We are thankful to Solange Brisson and Sara Oliveira for the first observation and alerting us about the occurrence of the animals at Cabo Frio (RJ). Collections were in accordance with Brazilian regulations (SISBIO licence 15031-2 to ACM). We thank Drs Oberdan J. Pereira (UFES), Thelma L.P. Dias (UEPB), Claudio L.S. Sampaio (UFAL) and Helena Matthews-Cascon and Bruno B. Batista (UFC) for recognizing and informing about photographic records in other regions. We also thank Dr Fábio Di Dario (NUPEM, UFRJ) and $\mathrm{Mr}$ Enzo C. Morandini for helping in field samples. Different parts of this manuscript were presented as posters at three 


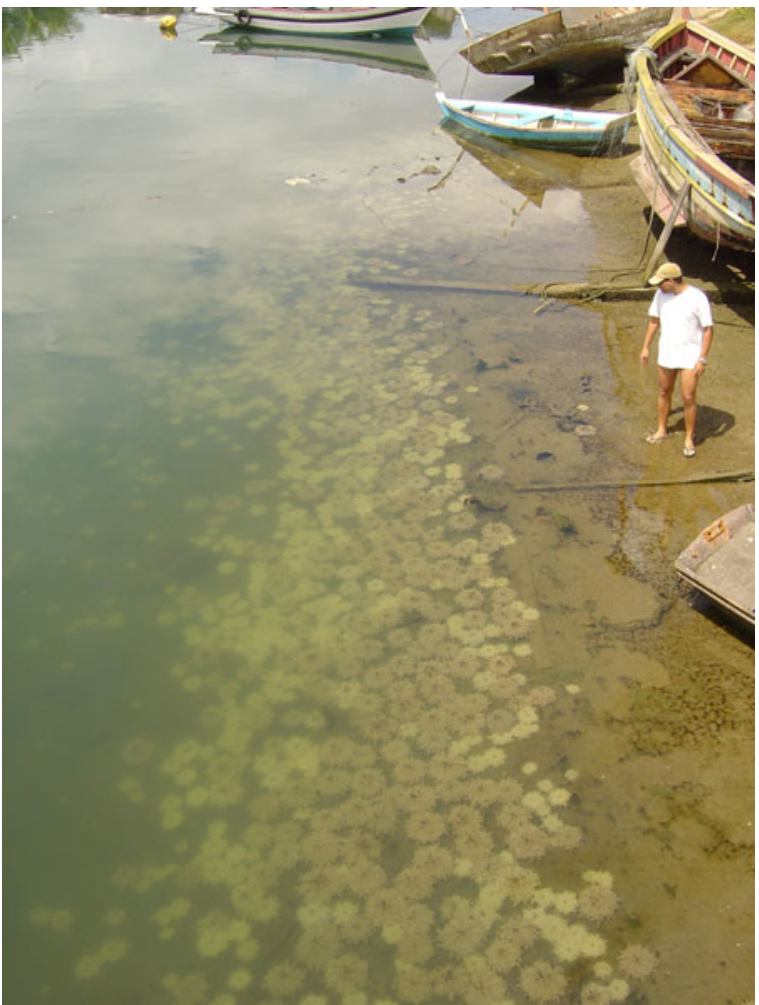

Fig. 5. Medusae of Cassiopea andromeda (Forskål, 1775) at a branch of Itajuru Channel (Cabo Frio, Rio de Janeiro State, Brazil) during December 2008. Note first author as scale $(\sim 1.65 \mathrm{~m})$.

conferences (II Congresso Brasileiro de Biologia Marinha, III International Jellyfish Blooms Symposium, II World Conference on Marine Biodiversity) and we thank all the audiences for further discussions. We are also indebted to Dr Mark J. Gibbons (UWC, South Africa) for corrections and comments on an earlier version of the text. We also thank two anonymous reviewers for comments and suggestions to improve the text.

\section{FINANCIAL SUPPDRT}

ACM was supported by grants 2010/50174-7, 2011/50242-5 and 2013/50484-4 São Paulo Research Foundation (FAPESP), and by CNPq $(301039 / 2013-5)$. SNS was supported by grant 2012/01771-9 São Paulo Research Foundation (FAPESP), and by CNPq (481549/2012-9). This is a contribution of NP-BioMar, USP.

\section{REFERENCES}

Agassiz A. and Mayer A.G. (1899) Acalephs from the Fiji Islands. Bulletin of the Museum of Comparative Zoology, at Harvard College 32, 157-189.

Anisimova M., Gil M., Dufayard J.-F., Dessimoz C. and Gascuel O. (2011) Survey of branch support methods demonstrates accuracy, power, and robustness of fast likelihood-based approximation schemes. Systematic Biology 60, 685-699.

Appeltans W., Ahyong S.T., Anderson G., Angel M.V., Artois T., Bailly N., Bamber R., Barber A., Bartsch I., Berta A.,
Błazewicz-Paszkowycz M., Bock P., Boxshall G., Boyko C.B., Brandão S.N., Bray R.A., Bruce N.L., Cairns S.D., Chan T.-Y., Cheng L., Collins A.G., Cribb T., Curini-Galletti M., Dahdouh-Guebas F., Davie P.J.F., Dawson M.N., De Clerck O., Decock W., De Grave S., de Voogd N.J., Domning D.P., Emig C.C., Erséus C., Eschmeyer W., Fauchald K., Fautin D.G., Feist S.W., Fransen C.H.J.M., Furuya H., Garcia-Alvarez O., Gerken S., Gibson D., Gittenberger A., Gofas S., Gómez-Daglio L., Gordon D.P., Guiry M.D., Hernandez F., Hoeksema B.W., Hopcroft R.R., Jaume D., Kirk P., Koedam N., Koenemann S., Kolb J.B., Kristensen R.M., Kroh A., Lambert G., Lazarus D.B., Lemaitre R., Longshaw M., Lowry J., MacPherson E., Madin L.P., Mah C., Mapstone G., McLaughlin P.A., Mees J., Meland K., Messing C.G., Mills C.E., Molodtsova T.N., Mooi R., Neuhaus B., Ng P.K.L., Nielsen C., Norenburg J., Opresko D.M., Osawa M., Paulay G., Perrin W., Pilger J.F., Poore G.C.B., Pugh P., Read G.B., Reimer J.D., Rius M., Rocha R.M., Saiz-Salinas J.I., Scarabino V., Schierwater B., Schmidt-Rhaesa A., Schnabel K.E., Schotte M., Schuchert P., Schwabe E., Segers H., Self-Sullivan C., Shenkar N., Siegel V., Sterrer W., Stöhr S., Swalla B., Tasker M.L., Thuesen E.V., Timm T., Todaro A., Turon X., Tyler S., Uetz P., van der Land J., Vanhoorne B., van Ofwegen L.P., van Soest R.W.M., Vanaverbeke J., Walker-Smith G., Walter C., Warren A., Williams G.C., Wilson S.P. and Costello M.J. (2012) The magnitude of global marine species diversity. Current Biology 22, 2189-2202.

Arai M.N. (2001) Pelagic coelenterates and eutrophication: a review. Hydrobiologia 451, 69-87.

Barros R.C., Rocha R.M. and Pie M.R. (2008) Human-mediated global dispersion of Styela plicata (Tunicata, Ascidiacea). Aquatic Invasions $4,45-57$.

Bayha K.M. and Graham W.M. (2014) Nonindigenous marine jellyfish: invasiveness, invisibility, and impacts. In Pitt K.A. and Lucas C.H. (eds) Jellyfish blooms. Dordrecht: Springer, pp. 45-77.

Bigelow R.P. (1892) On a new species of Cassiopea from Jamaica. Zoologischer Anzeiger 15, 212-214.

Brandt J.F. (1835) Prodomus descriptionis animalium ab H. Mertensio observatorum. Fasc. I. Polypos, Acalephas Discophoras et Siphonophoras, nec non Echinodermata continens. Recueil des Actes de la Séance Publique de l'Académie Impériale des Sciences de St. Pétersbourg 1834, 201-275.

Briski E., Ghabooli S., Bailey S.A. and MacIsaac H.J. (2012) Invasion risk posed by macroinvertebrates transported in ships' ballast tanks. Biological Invasions 14, 1843-1850.

Carlton J.T. (1987) Patterns of transoceanic marine biological invasions in the Pacific Ocean. Bulletin of Marine Science 41, 452-465.

Carlton J.T. (1996) Pattern, process, and prediction in marine invasion ecology. Biological Conservation 78, 97-106.

Carlton J.T. and Geller J.B. (1993) Ecological roulette: the global transport of nonindigenous marine organisms. Science 261, 78-82.

Carlton J.T. and Hodder J. (1995) Biogeography and dispersal of coastal marine organisms: experimental studies on a replica of a 16th-century sailing vessel. Marine Biology 121, 721-730.

Cevik C., Erkol I.L. and Toklu B. (2006) A new record of an alien jellyfish from the Levantine coast of Turkey - Cassiopea andromeda (Forsskål, 1775) [Cnidaria: Scyphozoa: Rhizostomea]. Aquatic Invasions 1, 196-197.

Condon R.H., Graham W.M., Duarte C.M., Pitt K.A., Lucas C.H., Haddock S.H.D., Sutherland K.R., Robinson K.L., Dawson M.N., Decker M.B., Mills C.E., Purcell J.E., Malej A., Mianzan H., Uye S. - I., Gelcich S. and Madin L.P. (2012) Questioning the rise of gelatinous zooplankton in the world's oceans. BioScience 62, 160-169. 
Dawson M.N. (2003) Macro-morphological variation among cryptic species of the moon jellyfish, Aurelia (Cnidaria: Scyphozoa). Marine Biology 143, 369-379.

Dawson M.N. (2005a) Renaissance taxonomy: integrative evolutionary analyses in the classification of Scyphozoa. Journal of the Marine Biological Association of the United Kingdom 85, 733-739.

Dawson M.N. (2005b) Incipient speciation of Catostylus mosaicus (Scyphozoa, Rhizostomeae, Catostylidae), comparative phylogeography and biogeography in south-east Australia. Journal of Biogeography 32, 515-533.

De Broyer C., Danis B. and 64 SCAR-MarBIN Taxonomic Editors (2011) How many species in the Southern Ocean? Towards a dynamic inventory of the Antarctic marine species. Deep-Sea Research Part II 58, 5-17.

Devin S. and Beisel J.-N. (2007) Biological and ecological characteristics of invasive species: a gammarid study. Biological Invasions 9, 13-24.

Drummond A.J., Ashton B., Buxton S., Cheung M., Cooper A., Duran C., Field M., Heled J., Kearse M., Markowitz S., Moir R., Stones-Havas S., Sturrock S., Thierer T. and Wilson A. (2011) Geneious v5.4. Available from http://www.geneious.com/

Edgar R.C. (2004) MUSCLE: multiple sequence alignment with high accuracy and high throughput. Nucleic Acids Research 32, $1792-1797$.

Fofonoff P.W., Ruiz G.M., Steves B. and Cartlon J.T. (2003) In ships or on ships? Mechanisms of transfer and invasion for nonnative species to the coasts of North America. In Ruiz G.M. and Carlton J.T. (eds) Invasive species: vectors, management strategies. Washington, DC: Island Press, pp. 152-182.

Folmer O., Black M., Hoeh W., Lutz R. and Vrijenhoek R. (1994) DNA primers for amplification of mitochondrial cytochrome $\mathrm{c}$ oxidase subunit I from diverse metazoan invertebrates. Molecular Marine Biology and Biotechnology 3, 294-297.

Forskål P. (1775) Descriptiones animalium avium, amphibiorum, piscium, insectorum, vermium; quae in intinere orientali observavit Petrus Forskål. Hauniae: ex officina Mölleri, 164 pp.

Galil B.S., Spanier E. and Ferguson W.W. (1990) The scyphomedusae of the Mediterranean coast of Israel, including two lessepsian migrants new to the Mediterranean. Zoologische Mededelingen 64, 95-105.

Gershwin L., Zeidler W. and Davie P.J.F. (2010) Medusae (Cnidaria) of Moreton Bay, Queensland, Australia. Memoirs of the Queensland Museum 54, 47-108.

Goldfarb A.J. (1914) Changes in salinity and their effects upon the regeneration of Cassiopea xamachana. Papers from the Tortugas Laboratory of the Carnegie Institution 6, 85-94.

Graham W.M. and Bayha K.M. (2007) Biological invasions by marine jellyfish. In Nentwig W. (ed.) Biological invasions. Berlin: Springer, pp. 239-255.

Guindon S., Dufayard J.F., Lefort V., Anisimova M., Hordijk W. and Gascuel O. (2010) New algorithms and methods to estimate maximum-likelihood phylogenies: assessing the performance of PhyML 3.o. Systematic Biology 59, 307-321.

Guo Q., Sax D.F., Qian H. and Early R. (2012) Latitudinal shifts of introduced species: possible causes and implications. Biological Invasions $14,547-556$.

Haddad M.A. and Nogueira M. Jr. (2006) Reappearance and seasonality of Phyllorhiza punctata von Lendenfeld (Cnidaria, Scyphozoa, Rhizostomeae) medusae in southern Brazil. Revista Brasileira de Zoologia $23,824-831$.

Haeckel E. (1880) Das system der Medusen. I, 2: system der Acraspeden. Jena: Gustav Fischer.
Heins A., Glatzel T. and Holst S. (2015) Revised descriptions of the nematocysts and the asexual reproduction modes of the scyphozoan jellyfish Cassiopea andromeda (Forskål, 1775). Zoomorphology 134, $351-366$.

Hofmann D.K., Neumann R. and Henne K. (1978) Strobilation, budding and initiation of scyphistoma morphogenesis in the rhizostome Cassiopea andromeda (Cnidaria: Scyphozoa). Marine Biology 47, $161-176$.

Holland B.S., Dawson M.N., Crow G.L. and Hofmann D.K. (2004) Global phylogeography of Cassiopea (Scyphozoa: Rhizostomeae): molecular evidence for cryptic species and multiple invasions of the Hawaiian Islands. Marine Biology 145, 1119-1128.

Hummelinck P.W. (1968) Caribbean Scyphomedusae of the genus Cassiopea. Studies of the Fauna of Curaçao and Caribbean Islands $25,1-57$.

Kramp P.L. (1961) Synopsis of the medusae of the world. Journal of the Marine Biological Association of the United Kingdom 40, 7-469.

Lesueur C.A. (1823) Descriptions of several new species of Ascidia. Journal of the Academy of Natural Sciences of Philadelphia 3, 2-8.

Light S.F. (1914) Some Philippine scyphomedusae, including two new genera, five new species, and one new variety. Philippine Journal of Science 9 Section D, 195-231.

Lopes R.M., Coradin L., Pombo V.B. and Cunha D.R. (2009) Informe sobre as espécies exóticas invasoras marinhas no Brasil. Brasília: MMA.

Ludwig F.-D. (1969) Die Zooxanthellen bei Cassiopea andromeda Eschscholtz 1829 (Polypen-Stadium) und ihre Bedeutung für die Strobilation. Zoologisches Jahrbuch Abteilung Anatomie 86, 238-277.

Mayer A.G. (1910) The medusae of the world. Volume III. The Scyphomedusae. Carnegie Institution of Washington Publication 109, 499-735.

Migotto A.E., Marques A.C., Morandini A.C. and Silveira F.L. (2002) Checklist of the Cnidaria Medusozoa of Brazil. Biota Neotropica 2, $1-30$.

Mills C.E. (2001) Jellyfish blooms: are populations increasing globally in response to changing ocean conditions? Hydrobiologia 451, 55-68.

Morandini A.C., Ascher D., Stampar S.N. and Ferreira J.F.V. (2005) Cubozoa e Scyphozoa (Cnidaria: Medusozoa) de águas costeiras do Brasil. Iheringia, Série Zoologia 95, 281-294.

Moreira M.G.B.S. (1961) Sôbre Mastigias scintillae sp. nov. (Scyphomedusae, Rhizostomeae) das costas do Brasil. Boletim do Instituto Oceanográfico, São Paulo 11, 5-30.

Pallas P.S. (1774) Spicilegia Zoologica. Quibus novae imprimis et obscurae animalium species iconibus, descriptionibus atque comentariis illustrantur cura P.S. Pallas, Fasciculus Decimus. Berlin: Berolini, Prostant apud Gottl. August. Lange.

Péron F. and Lesueur C.A. (1810) Tableau des caractères génériques et spécifiques de toutes les espèces de Méduses connues jusqu'à ce jour. Annales du Muséum National d'Histoire Naturelle, Paris 14, 325-366.

Radulovici A.E., Archambault P. and Dufresne F. (2010) DNA barcodes for marine biodiversity: moving fast forward? Diversity 2, 450-472.

Rocha R.M., Vieira L.M., Migotto A.E., Amaral A.C.Z., Ventura C.R.R., Serejo C.S., Pitombo F.B., Santos K.C., Simone L.R.L., Tavares M., Lopes R.M., Pinheiro U. and Marques A.C. (2013) The need of more rigorous assessments of marine species introductions: a counter example from the Brazilian coast. Marine Pollution Bulletin 67, 241-243.

Rodríguez-Labajos B., Binimelis R. and Monterroso I. (2009) Multi-level driving forces of biological invasions. Ecological Economics 69, 63-75. 
Sala O.E., Chapin F.S. III, Gardner R.H., Lauenroth W.K., Mooney H.A. and Ramakrishnan P.S. (1999) Global change, biodiversity and ecological complexity. In Walker B.H., Steffen W.L., Canadell J. and Ingram J.S.I. (eds) The terrestrial biosphere and global change: implications for natural and managed ecosystems. Cambridge: Cambridge University Press, pp. 304-328.

Sax D.F., Stachowicz J.J., Brown J.H., Bruno J.F., Dawson M.N., Gaines S.D., Grosberg R.K., Hastings A., Holt R.D., Mayfield M.M., O'Connor M.I. and Rice W.R. (2007) Ecological and evolutionary insights from species invasions. Trends in Ecology and Evolution 22, $465-471$

Schander C. and Willassen E. (2005) What can biological barcoding do for marine biology? Marine Biology Research 1, 79-83.

Schembri P.J., Deidun A. and Vella P.J. (2010) First record of Cassiopea andromeda (Scyphozoa: Rhizostomeae: Cassiopeidae) from the central Mediterranean Sea. Marine Biodiversity Records 3, e6.

Stampar S.N., Maronna M.M., Vermeij M.J.A., Silveira F.L. and Morandini A.C. (2012) Evolutionary diversification of banded tube-dwelling anemones (Cnidaria; Ceriantharia; Isarachnanthus) in the Atlantic Ocean. PLoS ONE 7, e41091.

Stiasny G. (1922) Ueber einige von Dr C.J. van der Horst bei Curaçao gesammelte Medusen. Bijdragen tot de Kennis der Fauna van Curaçao. Resultaten eener Reis van C.J. van der Horst in 192023 83-91.

Straehler-Pohl I. (2009) Die Phylogenie der Rhopaliophora (Scyphozoa und Cubozoa) und die Paraphylie der 'Rhizostomeae'. PhD thesis. Universität Hamburg, Hamburg, Germany.

Straehler-Pohl I., Widmer C.L. and Morandini A.C. (2011) Characterizations of juvenile stages of some semaeostome Scyphozoa
(Cnidaria), with recognition of a new family (Phacellophoridae). Zootaxa 2741, 1-37.

Tamura K., Peterson D., Peterson N., Stecher G., Nei M. and Kumar S (2011) MEGA5: molecular evolutionary genetics analysis using maximum likelihood, evolutionary distance, and maximum parsimony methods. Molecular Biology and Evolution 28, 2731-2739.

Thiel M.E. (1975) Bemerkungen zur Systematik der Gattung Cassiopea (Cepheida, Scyphomedusae). Mitteilungen aus dem Hamburgischen Zoologischen Museum und Institut 72, 25-46.

von Lendenfeld R. (1884) The scyphomedusae of the southern hemisphere. Part III. Proceedings of the Linnean Society of New South Wales 9, 259-306.

Williams R.J., Griffiths F.B., Van der Wal E.J. and Kelly J. (1988) Cargo vessel ballast water as a vector for the transport of non-indigenous marine species. Estuarine, Coastal and Shelf Science 26, 409-420.

and

Zerebecki R.A. and Sorte C.J.B. (2011) Temperature tolerance and stress proteins as mechanisms of invasive species success. PLOS ONE 6, e14806.

\section{Correspondence should be addressed to:}

A.C. Morandini

Departamento de Zoologia, Instituto de Biociências, Universidade de São Paulo, Rua do Matão, travessa 14, n. 101, São Paulo, SP 05508-090, Brazil

Email: acmorand@ib.usp.br 